\title{
Rumen dynamics of neutral detergent fiber in cattle fed low-quality tropical forage and supplemented with nitrogenous compounds ${ }^{1}$
}

\section{Cláudia Batista Sampaio², Edenio Detmann ${ }^{3}$, Isis Lazzarini ${ }^{2}$, Marjorrie Augusto de Souza ${ }^{2}$, Mário Fonseca Paulino ${ }^{3}$, Sebastião de Campos Valadares Filho ${ }^{3}$}

\author{
1 Projeto financiado pelo CNPq com apoio da FAPEMIG (Programa Pesquisador Mineiro). \\ 2 Programa de Pós-Graduação em Zootecnia, Universidade Federal de Viçosa, Viçosa-MG, CEP: 36571-000. \\ ${ }^{3}$ Departamento de Zootecnia - UFV. Pesquisador do CNPq.
}

\begin{abstract}
The aim of this work was to evaluate the effects of supplementation with nitrogenous compounds on rumen dynamics of neutral detergent fiber (NDF) in cattle fed low-quality tropical forage. Five crossbred heifers with average live weight of $180 \mathrm{~kg}$ and fitted with rumen cannulae were used. The animals were fed ad libitum with signal grass (Brachiaria decumbens Stapf.) hay, which had crude protein (CP) content of $4.86 \%$ of dry matter (DM). The five treatments were proposed in order to raise the $\mathrm{CP}$ level of diets to $0,2,4,6$, and 8 percentile points above the CP level of the forage. The supplement was a mixture of urea, ammonium sulfate, and albumin (4.5:0.5:1.0, respectively). The experiment was carried out according to a $5 \times 5$ Latin square design, with five experimental periods. The average CP levels in the diets were: 5.19 , $7.11,8.60,11.67$, and $13.02 \%$ on DM basis. The potentially degradable NDF was linearly increased according to the CP levels in diet up to $6.97 \%$ of CP. From this point, there was stabilization of estimates $(47.87 \%$ of NDF). The degradation rate of potentially degradable NDF was linearly increased with the CP levels in diets. The rumen flow of fibrous particles (L) showed a linear-response-plateau pattern according to the CP levels in diets. The plateau (maximum estimate) began on $7.24 \%$ of CP. The mean retention time in the rumen and the rumen fill effect of undegradable NDF were affect by the CP levels similarly to L, with plateau (minimum) beginning on 6.90 and $6.97 \%$ of CP, respectively.
\end{abstract}

Key Words: rumen degradation, rumen fill, signal grass, supplementation, urea

\section{Dinâmica ruminal da fibra em detergente neutro em bovinos alimentados com forragem tropical de baixa qualidade e suplemento com compostos nitrogenados}

RESUMO - Objetivou-se avaliar os efeitos da suplementação com compostos nitrogenados sobre a dinâmica ruminal da fibra em detergente neutro (FDN) em bovinos alimentados com forragem tropical de baixa qualidade. Foram utilizadas cinco novilhas mestiças Holandês $\times$ Zebu, com peso vivo médio inicial de $180 \mathrm{~kg}$, fistuladas no rúmen. A alimentação volumosa basal dos animais foi constituída por feno de capim-praquiátia(Brachiaria decumbens $\operatorname{Stapf})(4,86 \%$ de $\mathrm{PB}$, com base na MS), fornecido à vontade. Os cinco tratamentos avaliados foram definidos de acordo com o nível de suplementação protéica $(0,2,4,6$ e 8 pontos percentuais acima do nível de PB da forragem, utilizando-se como fonte de compostos nitrogenados mistura de uréia, sulfato de amônia e albumina, nas proporções de 4,5:0,5:1,0, respectivamente. O experimento foi constituído de cinco períodos experimentais, segundo delineamento em quadrado latino $5 \times 5$. Os níveis médios de PB nas dietas foram de 5,19; 7,19; 8,60; 11,67 e 13,02\%, com base na MS.Verificou-se elevação linear da fração potencialmente degradável da FDN até o nível de 6,97\% de PB, com platô estimado de 47,87\% da FDN. A taxa de degradação da fração potencialmente degradável da FDN aumentou linearmente com os níveis de PB da dieta. O fluxo ruminal de partículas fibrosas apresentou relação linear-response-plateau, com estabelecimento do platô (máximo) em 7,24\% de PB. O tempo médio de retenção no rúmen-retículo e a repleção ruminal da fração indegradável da FDN apresentaram comportamento semelhante ao fluxo ruminal de partículas fibrosas, com ponto crítico para o início do platô (mínimo) em 6,90 e 6,97\% de PB, respectivamente.

Palavras-chave: capim-braquiária, degradação ruminal, suplementação, repleção ruminal, uréia

Received September 24, 2007 and accepted August 13, 2008. Corresponding author: claudiabsampaio@yahoo.com.br 


\section{Introduction}

Tropical grasses present a high forage mass production along the year. However, as the maturation occurs, the forage mass accumulation is associated with thickening and high lignin accumulation in the cell wall. These alterations are constraints for microbial digestion and fermentation and decrease the forage quality (Paulino et al., 2002).

Tropical forages normally present crude protein (CP) content lower than $7 \%$, which is considered to be limiting to the microbial activity in the rumen (Minson, 1990). Under these circumstances, optimal rumen conditions (Ørskov, 2000), continuous microbial growth and adequate utilization of fibrous compounds will not be observed.

The optimal utilization of energy from forage fiber only will be reached by increasing the microbial utilization of potentially degradable fraction of neutral detergent fiber (NDF), which represents about $60 \%$ of tropical forages dry matter (DM) (Paulino et al., 2006).

The integration of the basal nutritional resources and the supplements must instigate the maximal approach between effectively degraded and potentially degradable fractions of NDF. It can be done by modifying the NDF degradation and passage, including the increase of passage of undegradable fraction of NDF, which cannot be used by rumen microorganisms in any feed situation (Paulino et al., 2006).

Protein is the main limiting nutrient for adequate lowquality forage utilization. Thus, protein supplementation is the recommended nutritional procedure, once it will provide adequate conditions for microbial growth and efficient utilization of forage fiber.

Several authors have reported positive associations between nitrogenous compounds supplementation and low-quality forage intake and digestibility (Delcurto et al., 1990; Hannah et al., 1991; Köster et al., 1996). However, such information associating rumen dynamics of fiber are still scarce in the tropics.

Therefore, the objective of this work was to evaluate the effects of nitrogenous compounds supplementation on rumen dynamics of neutral detergent fiber in cattle fed low-quality tropical forage.

\section{Material and Methods}

This experiment was carried out in the Animal Laboratory

- Department of Animal Science, Federal University of Viçosa (UFV), Viçosa, Brazil.
Five crossbred heifers $(\mathrm{H} \times \mathrm{Z})$ averaging $180 \pm 21 \mathrm{~kg}$ of body weight (BW) were surgically fitted with ruminal cannulae. The animals were treated for endo and ecto parasites at the beginning of the experiment and kept in individual stalls (which were daily cleaned) of approximately $10 \mathrm{~m}^{2}$. Water and mineral mixture were available to heifers at all time.

The forage offered to the animals consisted of lowquality signal grass (Brachiaria decumbens Stapf.) hay, with average $4.86 \%$ CP level, on dry matter (DM) basis.

The five treatments were proposed in order to raise the CP level of the diet to $0,2,4,6$ and 8 percentile points, on DM basis, above the CP level of the forage. A mixture of urea, ammonium sulfate and albumin was used as source of nitrogenous compounds, at the ratios of 4.5:0.5:1.0, respectively. The supplement was calculated based on the DM intake computed on the previous day and placed directly in the rumen of the animals.

The supplement ingredients were chosen based on their carbohydrate absence, so the effects of supplementation with nitrogenous compounds could be evaluated without any supplementary source of fiber or energy interfering in the measurements. The ratio of urea on ammonium sulfate was fixed at 9:1 (or 4.5:0.5) as it is normally used in cattle diets. Albumin was included in the supplement to meet the microbial requirements of true degradable protein, allowing the supply of essential substrates such as branched-chain volatile fatty acids.

The forage was supplied ad libitum, allowing approximately $10 \%$ in orts, being fed twice a day in equal portions, at 8 a.m. and 4 p.m. The supplements, in two portions of equal weight, were placed in the rumen of the animals when the forage was offered. The forage offered and the orts were daily quantified.

The experiment consisted of five 16-day experimental periods. The first five days of each experimental period were used to the adaptation of the animals to the supplementation levels.

For the quantification of DM and NDF voluntary intake, feedstuffs supplied between the sixth and the ninth days of each experimental period were considered and the orts were considered between the seventh and tenth day.

Forage and orts samples were processed in a Willey mill (1 mm) and stored for later analyses.

To evaluate the rumen ammonia nitrogen (RAN) concentration, rumen fluid samples were collected on the sixth day of each experimental period at 4 a.m., 8 a.m., 12 p.m., 4 p.m., 8 p.m. and 12 a.m. The samples were manually collected from the liquid:solid interface of the 
rumen matand filtered through a triple layer of cheesecloth. After that, a $40 \mathrm{~mL}$ aliquot was then separated, fixed with $1 \mathrm{~mL} \mathrm{H}_{2} \mathrm{SO}_{4}(1: 1)$ and frozen $\left(-20^{\circ} \mathrm{C}\right)$ for later analysis .

The evaluation of transit kinetics of fibrous particles was done between the $11^{\text {th }}$ and the $16^{\text {th }}$ day of each experimental period through a pulse dose of fiber mordant chromium (Ellis et etl., 1994). Signal grass hay samples were used for mordant production according to procedures described by Udén et al. (1980).

On the $11^{\text {th }}$ day of each experimental period, approximately $100 \mathrm{~g}$ of mordant fiber were placed in the rumen of the animals at 8 a.m. Fecal samples were collected from the rectum of the animals at $0,3,6,9,12,15,18,21,24,30,36$, $42,48,60,72,84,96,120$, and 144 hours after marker administration. The samples were oven dried $\left(60^{\circ} \mathrm{C} / 72\right.$ hours) and processed in a Willey mill $(1 \mathrm{~mm})$.

Simultaneously to the transit evaluation, in situ incubation was carried out to estimate the rumen degradation parameters of NDF. Hay samples were processedin a Willey mill (2 mm) (NRC, 2001) and placed in non-woven textile $\left(100 \mathrm{~g} / \mathrm{m}^{2}\right)$ bags in a ratio of $20 \mathrm{mg} \mathrm{DM} / \mathrm{cm}^{2}$ ofbag surface. The bags, in duplicate for each incubation time, were placed in the rumen of the animals. The following incubation times were used: $0,3,6,9,12,18,24,36,48,72$, 96 and 120 hours. The incubation times were set in reverse order to allow the removal of all bags at the same time. After incubation, the bags were cleaned with tap water and oven dried $\left(60^{\circ} \mathrm{C}\right)$. The residual NDF contents were determined in a fiber analyzer $\left(\right.$ Ankom $\left.^{200}\right)$.

Samples of feeds and orts were analyzed regarding $\mathrm{DM}$, organic matter (OM), and CP contents according to methods of Silva \& Queiroz (2002). In the NDF analysis, the samples were treated with a heat stable alpha amylase, without using sodium sulphite (Mertens, 2002). There were no corrections for residual ash or nitrogen. The supplement samples were analyzed regarding DM, OM and CP, as described above (Table 1).

The RAN content in rumen fluid samples was determined through micro-Kjeldahl system, without acid digestion and after distillation with potassium hydroxide

Table 1 - Average contents of dry matter (DM), organic matter $(\mathrm{OM})$, crude protein $(\mathrm{CP})$ and neutral detergent fiber (NDF) in hay and supplement

\begin{tabular}{lcc}
\hline Item & Hay & Supplement \\
\hline $\mathrm{DM}^{1}$ & 89.96 & 89.64 \\
$\mathrm{OM}^{2}$ & 94.26 & 98.91 \\
$\mathrm{CP}^{2}$ & 4.86 & 251.20 \\
$\mathrm{NDF}^{2}$ & 83.04 & - \\
\hline
\end{tabular}

$1 \%$ as fed; ${ }^{2} \%$ of DM.
$(2 \mathrm{~N})$, after previous sample centrifugation at $1,000 \times g$, for $15 \mathrm{~min}$. The concentrations obtained at the different sampling times were combined by animal and period in order to obtain a single value that represented the average daily RAN concentration.

The feces samples used to evaluate the transit kinetics parameters were analyzed regarding DM (Silva \& Queiroz, 2002) and chromium (Williams et al., 1962).

The transit kinetics parameters were estimated through adjustment of a gama-2 time-dependent model to the chromium excretion profiles (Ellis et al., 1994):

$C_{t}=Z \times(t-\tau) \times L \times \exp [-L \times(t-\tau)]$

where $C_{t}$ is the fecal concentration of chromium at time " $t$ " $(\mathrm{ppm}), \mathrm{t}$ the time after marker administration (h), L the timedependent rate parameter related to rumen flow of fibrous particles $\left(\mathrm{h}^{-1}\right), \mathrm{Z}$ a parameter without biological meaning $(\mathrm{ppm} \times \mathrm{h})$, and $\tau$ the time of intestinal transit $(\mathrm{h})$.

The estimates of mean retention time in the rumen and in total gastrointestinal tract were obtained from parameter estimates obtained in (1), according to the following equations (Ellis et al., 1994):

$M R T R=\frac{2}{L}$

$M R T T=M R T R+\tau$

where MRTR is the mean retention time in the rumen (h), and MRTT the mean retention time in gastrointestinal tract (h).

The NDF degradation profiles were evaluated according to logistic model of Van Milgen et al. (1991):

$R_{t}=B \times(1+\lambda \times t) \times \exp (-\lambda \times t)+U$

where $\mathrm{R}_{\mathrm{t}}$ is the non-degraded NDF residue at time " $\mathrm{t}$ " $(\%)$, $\mathrm{B}$ the potentially degradable fraction $(\%)$, $\mathrm{U}$ the undegradable fraction (\%), and $\lambda$ the common rate of lag and degradation $\left(\mathrm{h}^{-1}\right)$.

The NDF fractional degradation rate was estimated from $\lambda$ by using the properties of gama- 2 distribution (Ellis et al., 1994):

$k=0,59635 \times \lambda$

where $\mathrm{k}$ is the fractional degradation rate of potentially degradable fraction of NDF $\left(\mathrm{h}^{-1}\right)$.

The discrete lag estimates were obtained according to Vieira et al. (1997): 
$L A G=\frac{R(0)-R\left(t_{i}\right)}{R^{\prime}\left(t_{i}\right)}+t_{i}$

where LAG is the discrete lag $(\mathrm{h}), \mathrm{R}(0)$ is the non-degraded NDF residue at $\mathrm{t}=0, \mathrm{R}\left(\mathrm{t}_{\mathrm{i}}\right)$ the non-degraded NDF residue at inflection point of degradation profile $(\%), \mathrm{R}^{\prime}\left(\mathrm{t}_{\mathrm{j}}\right)$ the mathematical derivative of degradation profile at inflection point (maximum degradation rate) $\left(\mathrm{h}^{-1}\right)$, and $\mathrm{t}_{\mathrm{i}}$ the time at inflection point $(\mathrm{h})$.

The $t_{i}$ values were obtained according to Vieira et al. (1997):

$t_{i}=\frac{1}{\lambda}$

The $\mathrm{B}$ and $\mathrm{U}$ fractions were evaluated after a standardization procedure (Waldo et al., 1972):

$$
\begin{aligned}
& B p=\frac{B}{B+U} \\
& U p=\frac{I}{B+U}
\end{aligned}
$$

The effectively degraded fraction of NDF was estimated by adapting the suggestions of Ørskov \& McDonald (1979):

$$
E D F=\lim _{t \rightarrow \infty} \int_{0}^{t}\left[f(t) \times\left(-\frac{d R t}{d t}\right)\right] d t
$$

where EDF is the effectivelydegraded fraction of $\operatorname{NDF}(\%)$, and $f(\mathrm{t})$ the mathematical function thatdescribes the solid transit throughout the rumen.

The function $f(\mathrm{t})$ was obtained by reparameterization of (1), where the excretion profile was changed from emerging particles into resident particles (Ellis et al., 1994):

$f(t)=(1+L \times t) \times \exp (-L \times t)$

The estimates of the rumen fill effect of NDF were obtained by adapting the method of Waldo et al. (1972):

$R F_{1}=\lim _{t \rightarrow \infty} \int_{0}^{t}[B p \times(1+\lambda \times t) \times \exp (-\lambda \times t) \times(1+L \times t) \times \exp (-L \times t)] d t$

$R F_{2}=\lim _{t \rightarrow \infty} \int_{0}^{t}[U p \times(1+L \times t) \times \exp (-L \times t)] d t$

$R F_{t}=R F_{1}+R F_{2}$

where $\mathrm{RF}_{t}$ is the total rumen fill effect of NDF (h), $\mathrm{RF}_{1}$ the rumen fill effect of potentially degradable fraction of $\mathrm{NDF}(\mathrm{h})$, and $\mathrm{RF}_{2}$ the rumen fill effect of undegradable fraction of NDF $(h)$.
The experimental design was a $5 \times 5$ Latin square with five supplementation levels, five animals and five experimental periods. The average dietary CP content in each supplementation level was used as independent variable for interpretation of the effects of treatments. The comparisons between treatments were conducted using linear regression and correlation methods (Myers, 1990). All adjustments of non-linear models were performed according to the Gauss-Newton iterative algorithm (Souza, 1998).

All the statistical procedures were carried out using SAS (Statistical Analysis System) $(\alpha=0.05)$.

\section{Results and Discussion}

The average CP levels in diets, which were calculated from the ratio between the total $\mathrm{CP}$ intake (forage and supplement) and the total DM intake, were 5.19, 7.11, 8.60, 11.67 and $13.02 \%$, on DM basis, for supplementation levels of $0,2,4,6$ and $8 \%$, respectively.

The potentially degradable fraction of NDF was linearly increased $(\mathrm{P}<0.05)$ up to $6.97 \%$ of $\mathrm{CP}$ (Figure 1; Table 2). From this point, the values became unchangeable, with plateau estimate of $47.87 \%$ of NDF. Since potentially degradable and undegradable fractions complement each other, the latter variable presented a similar pattern (Table 2) according to the CP levels in the diet $(\mathrm{P}<0.05)$; however the relationship was negative during the linear phase of the profile ( $\hat{\mathrm{Y}}=121.8539-10.010 \mathrm{X} ; \forall \mathrm{X} \leq 6.9655$; $\left.\hat{\mathrm{Y}}=52.1267 ; \forall \mathrm{X}>6.9655 ; \mathrm{R}^{2}=0.9364\right)$.

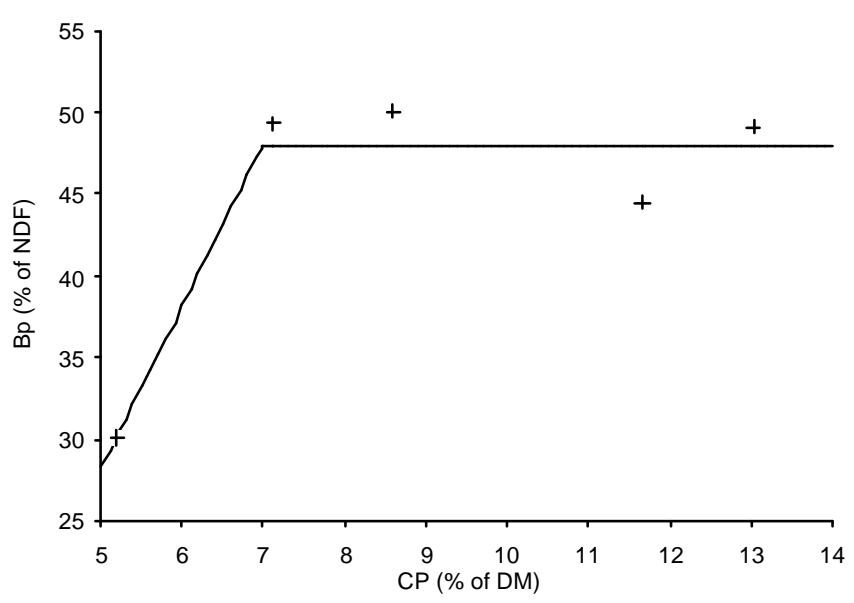

Figure 1 - Relationship between crude protein (CP) content in the diet and standard potentially degradable fraction of neutral detergent fiber (Bp) ( $\hat{\mathrm{Y}}=-21.8909+10.016 \mathrm{X}$; $\forall \mathrm{X} \leq 6.9652 ; \hat{\mathrm{Y}}=47.8700 ; \forall \mathrm{X}>6.9652$; $\left.\mathrm{R}^{2}=0.9365\right)$. 
Table 2 - Estimates of transit and degradation dynamics parameters, NDF intake, and RAN concentration according to the $\mathrm{CP}$ levels in the diet

\begin{tabular}{lcccccc}
\hline & \multicolumn{5}{c}{ CP level (\%) } & \multicolumn{2}{c}{ CV (\%) } \\
\cline { 2 - 6 } Item $^{1}$ & 5.19 & 7.11 & 8.60 & 11.67 & 13.02 & \\
\hline BP & 30.09 & 49.32 & 50.03 & 44.45 & 49.13 & 10.4 \\
Up & 69.90 & 50.68 & 49.97 & 55.55 & 50.86 & 8.6 \\
k & 0.1394 & 0.1998 & 0.1896 & 0.2072 & 0.2438 & 8.2 \\
LAG & 1.25 & 0.84 & 0.90 & 0.83 & 0.69 & 8.7 \\
EDF & 29.73 & 48.64 & 49.35 & 43.80 & 48.28 & 10.3 \\
L & 0.0102 & 0.0130 & 0.0129 & 0.0128 & 0.0139 & 19.1 \\
t & 8.62 & 8.11 & 7.75 & 8.04 & 7.61 & 10.1 \\
MRTR & 220.04 & 155.58 & 161.94 & 170.46 & 155.61 & 30.6 \\
MRTT & 228.66 & 163.70 & 169.69 & 178.51 & 163.22 & 29.6 \\
RF $_{1}$ & 2.38 & 2.69 & 2.92 & 2.36 & 2.19 & 18.0 \\
RF $_{2}$ & 132.62 & 76.02 & 75.81 & 88.86 & 75.18 & 32.3 \\
RR $_{\text {t }}$ & 135.01 & 78.72 & 78.73 & 91.21 & 77.35 & 31.0 \\
NDFI $_{\text {RAN }}^{10.7}$ & 12.5 & 13.7 & 13.8 & 12.5 & 14.9 \\
RAN & 3.82 & 6.32 & 9.62 & 8.72 & 14.24 & 38.1 \\
\hline
\end{tabular}

${ }^{1} \mathrm{Bp}$ - standard potentially degradable fraction of NDF (\%); Up - standard undegradable fraction of $\operatorname{NDF}(\%) ; \mathrm{k}$ - fractional degradation rate of potentially degradable fraction of NDF $\left(\mathrm{h}^{-1}\right)$; LAG - discrete lag (h); EDF - effectively degraded fraction of NDF (\%); $\mathrm{L}$ - time-dependent rate parameter related to rumen flow of fibrous particles $\left(\mathrm{h}^{-1}\right) ; \tau$ - time of intestinal transit (h); MRTR mean retention time in the rumen (h); MRTT - mean retention time in the gastrointestinal tract $(\mathrm{h}) ; \mathrm{RF}_{1}$ - rumen fill effect of potentially degradable NDF (h); $\mathrm{RF}_{2}$ - rumen fill effect of undegradable $\mathrm{NDF}(\mathrm{h}) ; \mathrm{RF}_{\mathrm{t}}$ - total rumen fill effect of $\mathrm{NDF}^{(\mathrm{h})}$; NDFI - NDF voluntary intake $(\mathrm{g} / \mathrm{kg} \mathrm{LW})$; RAN - rumen ammonia nitrogen concentration $(\mathrm{mg} / \mathrm{dL})$.

These patterns apparently contradict the theoretical definition of potentially degradable (and undegradable) fraction, whose dimension must be defined only by substrate characteristics (Ørskov, 2000) and is not (and can not be) influenced by characteristics of the microbial growth environment.

However, the nitrogenous compounds requirements of rumen microorganisms are no longer completely supplied under dietary $\mathrm{CP}$ levels below 6-8\%, which could constraint the utilization of energy substrates in the rumen (Van Soest, 1994). Thus, the reduction of Bp estimates at CP levels below $6.97 \%$ (near $7 \%$ ) does not indicate a true reduction, but only an apparent transformation of part of potentially degradable fraction into undegradable fraction caused by deficiency of microbial enzymatic systems for degrading the forage fibrous components. It must be emphasize that, under these circumstances, the enzymatic deficiency is mainly defined by the nitrogen deficiency for the synthesis of amino acids, which would compound the microbial enzymes. Therefore, the actual size of the potentially degradable fraction remains constant, because it is just a characteristic of the substrate (Ørskov, 2000) and cannot be altered by rumen conditions or by the CP level in the diet.

Most assumptions applied to rumen NDF degradation dynamics consider that fibre degradationcan bedescribed by first-order models. In this case, biological events depend on a single pool, assuming substrate as the limiting variable. Therefore, intrinsic characteristics of the substrate would be the single restrictive factor for rumen degradation, as a large and non-limiting enzymatic pool would exist in the rumen (Mertens, 2005; Detmann et al., 2008).

However, according to the Bp pattern (and Up) (Figure 1), two different phases of rumen degradation dynamics can be defined. When $\mathrm{CP}$ content in the diet is above $7 \%$, there will be "complete" estimates of potentially degradable fraction. It indicates that the enzymatic characteristics in the rumen do not limit the fiber utilization by microorganisms and the degradation is a typical firstorder process. On the other hand, the "incomplete" estimates of potentially degradable fraction, which are observed when $\mathrm{CP}$ level is below $7 \%$ are showing that the degradation process become dependent of the substrate characteristics and enzymatic pool in the rumen.

Thus, the increasing CP levels in the diet characterize the rumen degradation dynamics of NDF as a secondorder process (or Michaelis-Menten process) (Mertens, 2005 ). In other words, the deficiency of enzymatic systems at CP levels below 7\% implies predominance of zero-order reactions (where the dynamics is defined by enzyme deficiency), which are converted into first-order reactions (where the dynamics is defined by substrate characteristics), since nitrogenous compounds are included in the diet. Therefore, supplementation with nitrogenous compounds causes increase in the enzymatic system pool in the rumen.

Detmann et al. (2005) reported some evidences of NDF degradation as second-order process. These authors carried out an in vitro assay of gas production and observed that the NDF degradation rate of forage incubated together with supplement was higher than degradation rates when they were incubated separately.

The results of this study are in accordance with results obtained by Ortiz-Rubio et al. (2007), who found increase in the potentially fraction of dry matter when they supplied nitrogenous compounds to cattle fed sugarcane tops $(5.38 \%$ of $\mathrm{CP})$.

The difference between the estimates of Bp at CP levels below $7 \%$ and the true value of this fraction (47.87\% of NDF) agrees with the concept of "latent energy", which was defined by Paulino et al. (2001). These authors reported that, under deficiency of nitrogenous compounds in the diet, part of the energy substrates of forage, which could be potentially used, becomes effectively unusable due to the deficiency of microbial enzymatic systems. 
In this context, it could be inferred that $7 \%$ is the minimal CP level in the diet to give rumen microorganisms full ability to use energy from fibrous substrates.

The RAN concentration shows a linear and positive pattern in function of the CP levels in the diet $(\mathrm{P}<0.05)$ $\left(\hat{\mathrm{Y}}=-1.12+1.0511 \mathrm{X} ; \mathrm{r}^{2}=0.7921\right)$. The change of CP level into RAN concentration indicates that the Bp plateau (Figure 1) begins on $6.24 \mathrm{mg}$ of NAR/dL, which can be understood as minimal concentration necessary for sustaining an adequate microbial activity on NDF from basal forage. This estimate is higher than that related by Sampaio et al. (2002) (5.32 mg/dL) for maintenance of microbial activity in the rumen. These authors reported $9.64 \mathrm{mg} / \mathrm{dL}$ as the RAN level associated with maximum forage intake. The estimate of RAN obtained in this work was far higher than that suggested by Satter \& Slyter (1974) (5 mg/dL).

The degradation rate of potentially degradable NDF was positively and linearly associated with $\mathrm{CP}$ levels in the $\operatorname{diet}(\mathrm{P}<0.05)\left(\hat{\mathrm{Y}}=0.1007+0.0104 \mathrm{X} ; \mathrm{r}^{2}=0.7979\right)$. On the other hand, the discrete lag was linear and negatively associated with CP levels $(\mathrm{P}<0.05)(\hat{\mathrm{Y}}=1.3907-0.0535 \mathrm{X}$; $\mathrm{r}^{2}=0.6971$ ) (Table 2).

The linear increase in the degradation rate according to CP levels in the diet agrees with Satter \& Slyter (1974), who affirmed that the microbial yield on the substrate increases linearly up to CP levels near 13-14\%. This pattern can be supported by the fact that the microbial protein production is directly related to the velocity of energy substrates utilization, which is nearly associated with the NDF degradation rate in forage-based diets.

The discrete lag estimates the time spent with preparatory events for fiber degradation, such as physical (e.g. particle hydration, mastication, etc) and microbiological aspects (e.g. adhesion, enzymes synthesis, etc). In this context, the decrease in lag as the CP level increases indicates an adequacy of the rumen environment for microbial growing.

The estimates of NDF degradation rate of this study are higher than those normally reported for tropical forages (Vieira et al., 1997; Casali et al., 2008). However, similar estimates were obtained by Lazzarini (2007), who fed cattle with low-quality tropical forage (Brachiaria decumbens).

It must be emphasized that the experimental diet conditions in this work and in the work of Lazzarini (2007) were atypical, where NDF from low-quality forage was basically the only source of carbohydrates for microbial growth, with non-fibrous carbohydrates (NFC) intake below metabolic fecal excretion (Lazzarini, 2007; Sampaio et al., 2009).
An excess of NFC in the diet leads to negative effects on NDF degradation, which is called "carbohydrate effect" (Mould et al., 1983; Arroquy et al., 2005; Costa et al., 2008). This effect seems to be associated with release of inhibiting compounds by starch degrading microorganisms (El-Shazly et al., 1961) or with competition by essential substrates between groups of microbial species (Coelho da Silva \& Leão, 1979).

In this context, the ruminal conditions in this study and in the work of Lazzarini (2007) could have lead to extreme reduction or elimination of the "carbohydrate effect", which would allow the predominant development of fiber degrading bacteria, without inhibition or competition with NFC degrading bacteria. It could lead to higher degradation rates when compared to normal feed conditions.

In spite of high values, the tendency of the estimates confirms the observation of stimulus on microbial growth with nitrogenous compounds supplementation (Table 2).

Although the potentially degradable fraction of NDF can be totally considered as energy resource for animal production, it is an asymptotical concept (Mertens, 2005). In other words, it can only be valid if the degradation time is infinite. However, in practice, degradation events occur in a finite time.

In this context, the optimization of basal nutritional resources, considering the interaction with supplements, must be based on maximal approach between effectively degraded fraction (EDF) and potentially degradable fraction of NDF, since no disturbance occurred in the voluntary intake (Paulino et al., 2006).

The EDF pattern in function of the CP levels in the diet was similar to the Bp pattern $(\mathrm{P}<0.05)$ (Figure 2$)$.

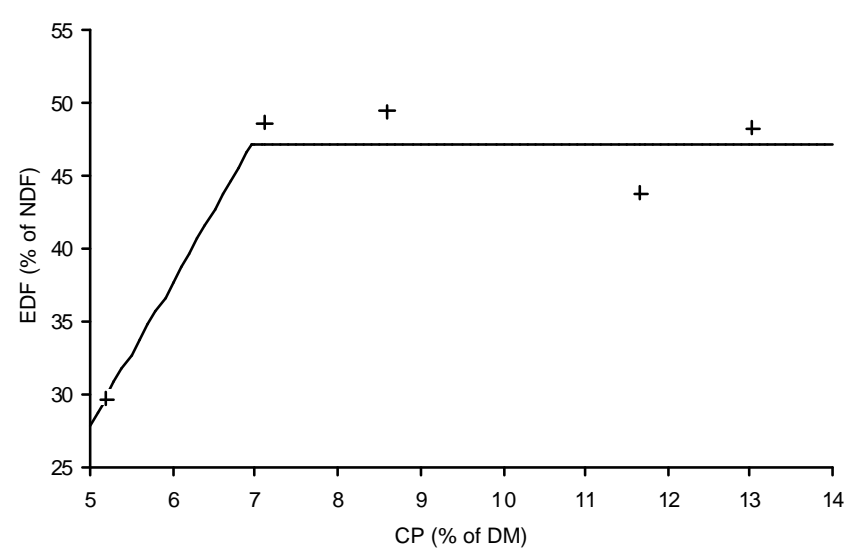

Figure 2 - Relationship between the crude protein $(\mathrm{CP})$ level in the diet and the effectively degraded fraction (EDF) of $\operatorname{NDF}(\hat{\mathrm{Y}}=-21.3862+9.849 \mathrm{X} ; \forall \mathrm{X} \leq 6.9580$; $\left.\hat{\mathrm{Y}}=47.1433 ; \forall \mathrm{X}>6.9580 ; \mathrm{R}^{2}=0.9363\right)$. 
A LRP pattern $(\mathrm{P}<0.05)$ was observed for ruminal flow of fibrous particles in function of the CP levels in the diet, with critical point for plateau beginning on $7.24 \%$ of $\mathrm{CP}$ (Figure 3).

The degradation and transit processes should be evaluated in an integrated way, once the time necessary for the particle to reach a specific gravity that caused the outflow decreases as the velocity of utilization of potentially degradable compounds increases (Allen, 1996). Thus, the $\mathrm{L}$ pattern reflects, at least in part, the pattern observed for the NDF degradation dynamics.

The estimates of MRTR ( $\hat{\mathrm{Y}}=394.28-33.5730 X$; $\left.\forall \mathrm{X} \leq 6.90 ; 162.67 ; \forall \mathrm{X}>6.90 ; \mathrm{R}^{2}=0.9623\right)$ and MRTT $(\hat{Y}=404.25-33.8330 X ; \forall X \leq 6.91 ; \hat{Y}=170.47 ; \forall X>6.91$; $\left.\mathrm{R}^{2}=0.9610\right)$ presented the same patternas $\mathrm{L}(\mathrm{P}<0.05)$. This similarity reflects the fact that MRTR and MRTT are obtained by the reciprocal of L (Equations 2 and 3). The intestinal transit time $(\tau)$ was not affected by the CP levels in the diet $(\mathrm{P}>0.05)$ (Table 2).

The disappearance of NDF from the rumen is a timedependent process, where the velocities of degradation of potentially degradable fraction and the transit of nondegraded and undegradable fractions become integrated (Ellis et al., 1994). These parameters, together with low NDF density, are the main factors that affect the voluntary intake of forage-based diets (Detmann et al., 2003). The disappearance dynamics of NDF from the rumen can be measured by the rumen fill effect (Waldo et al., 1972).

Under the assumption of steady state in the rumen, it can be assumed for diets based on fibrous feeds (as tropical pastures) that the NDF mass in the rumen is approximately constant. Therefore, new inputs of fibrous substrates will occur when part of resident mass is

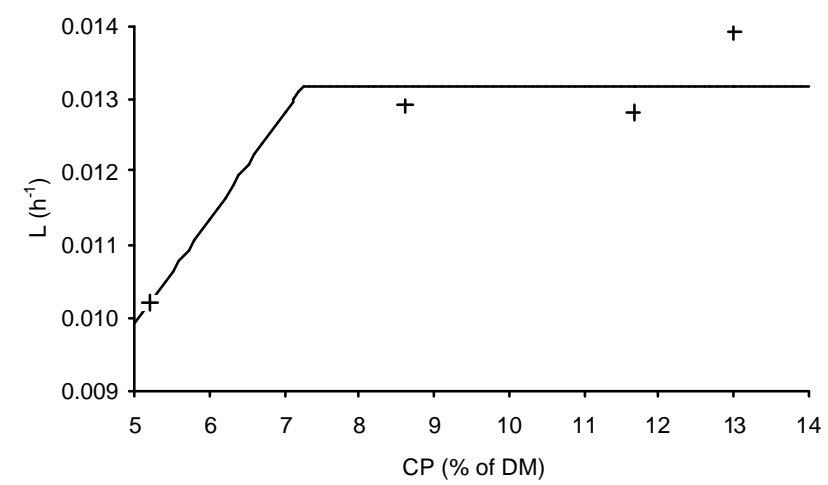

Figure 3 - Relationship between crude protein (CP) levels in the diet and the time-dependent rate parameter related to the rumen flow of fibrous particles (L) $(\hat{Y}=0.0026+0.00146 X ; \forall X \leq 7.2471 ; \hat{Y}=0.0132$; $\left.\forall \mathrm{X}>7.24 ; \mathrm{R}^{2}=0.8965\right)$. removed from the rumen by degradation or passage (Paulino et al., 2006). Thus, when such diets are supplied to the animals, the increase in the potentially degradable NDF utilization has the increase in the rumen input as primary determinant factor. It can be interpreted as the decrease of rumen fill effect (Equations 12, 13, and 14).

Although the supplementation did not affect the rumen fill effect of potentially degradable NDF $\left(\mathrm{RF}_{1}\right)(\mathrm{P}>0.05)$, a LRP pattern $(\mathrm{P}<0.05)$ was observed for rumen fill effect of undegradable NDF according to the CP levels in the diet $\left(\mathrm{RF}_{2}\right.$; Figure 4). It results in a similar pattern for total rumen fill effect of NDF $\left(\mathrm{RF}_{\mathrm{t}}\right)(\hat{\mathrm{Y}}=287.1685-29.3180 ; \forall \mathrm{X} \leq 6.98$; 82.43; $\left.\forall \mathrm{X}>6.98 ; \mathrm{R}^{2}=0.9518\right)$. These results corroborate the CP level of $7 \%$ as the minimal level to provide nitrogenous compounds for adequate microbial activity on NDF from low-quality forage.

In this study, $\mathrm{RF}_{2}$ was 26.0 to 55.7 times higher than $\mathrm{RF}_{1}$ (Table 2). Thus, the rumen dynamics of undegradable NDF seems to be priority to increase the NDF intake and to understand the interaction between forage and supplement.

Despite of constant estimate of $\mathrm{RF}_{2}$ from $7 \%$ of $\mathrm{CP}$, results reported by Sampaio et al. (2009) showed that the voluntary intake of dry matter and undegradable NDF is maximized at $10 \%$ of the $\mathrm{CP}$. This behavior corroborates the outflow of undegradable NDF as a determinant factor of the voluntary intake of low-quality forages.

The intake of NDF from basal forage must be increased in pasture-based production systems, once the energy from forage presents low cost (Paulino et al., 2006).

In this context, it was observed that the NDF intake was positively correlated with potentially degradable and effectively degraded NDF fractions and with rumen flow

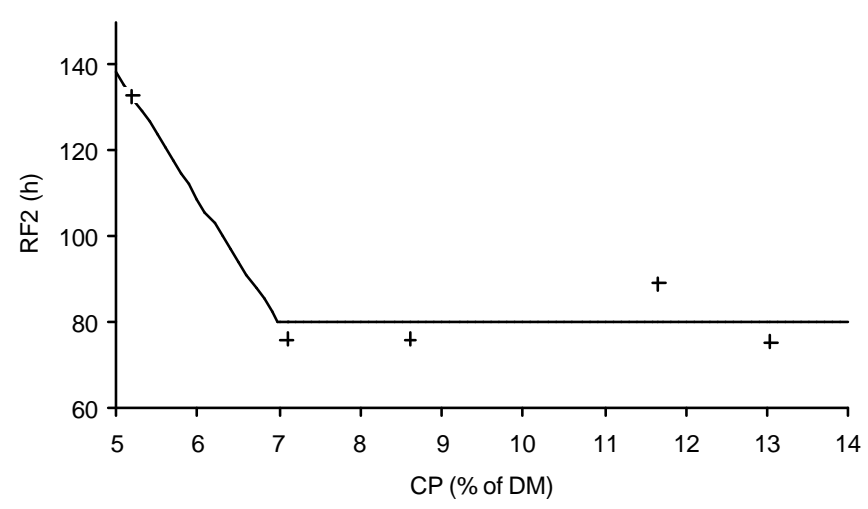

Figure 4 - Relationship between crude protein (CP) level in the diet and rumen fill effect of undegradable fraction of $\mathrm{NDF}\left(\mathrm{RF}_{2}\right) \quad(\hat{\mathrm{Y}}=285.6166-29.479 \mathrm{X} ; \forall \mathrm{X} \leq 6.97$; $\left.\hat{\mathrm{Y}}=79.95 ; \forall \mathrm{X}>6.97 ; \mathrm{R}^{2}=0.9510\right)$. 


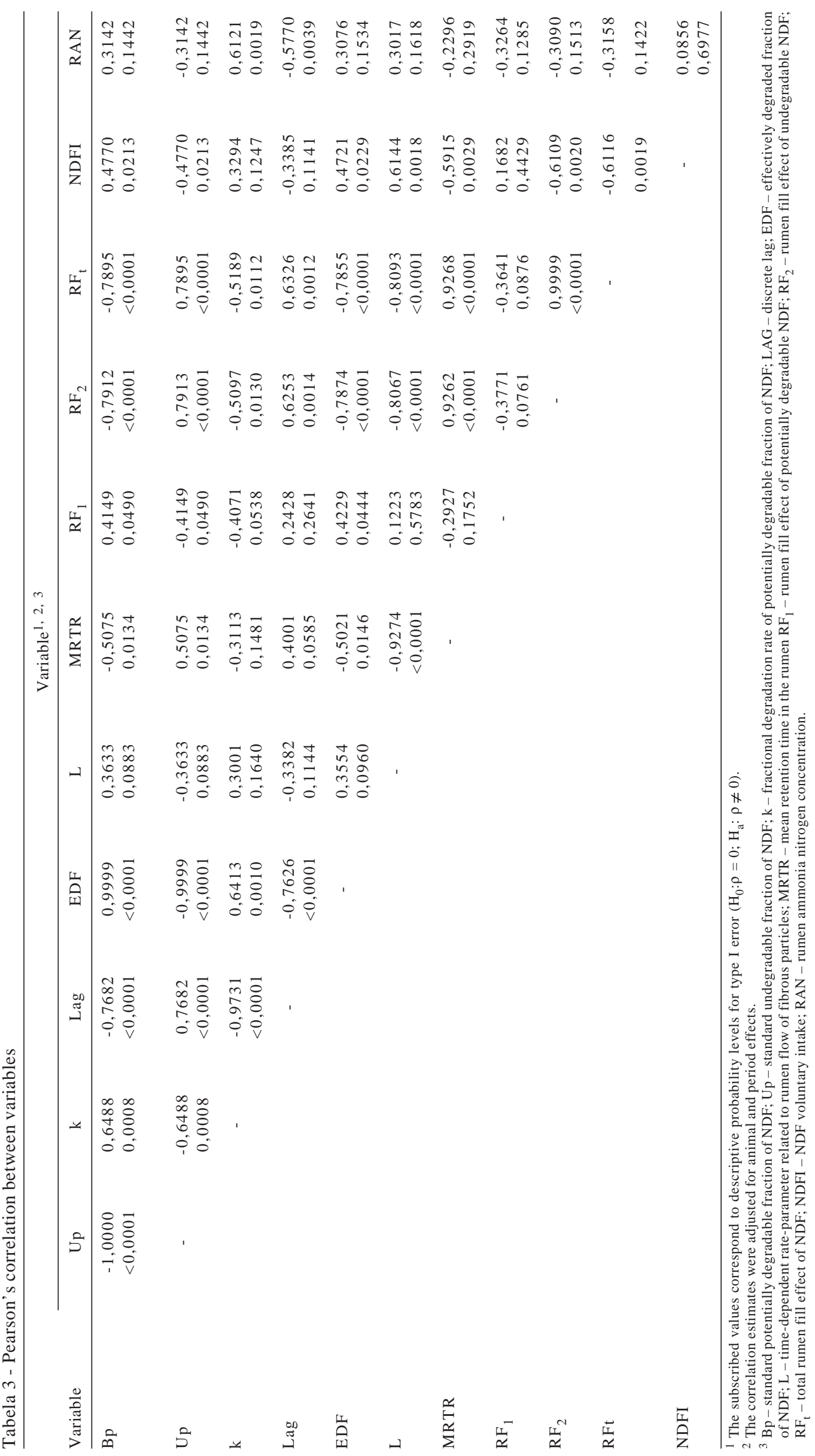


of fibrous particles $(\mathrm{P}<0.05)$, and negatively correlated with $\mathrm{RF}_{2}(\mathrm{P}<0.05)$ (Table 3$)$.

The RAN concentration was not correlated with the NDF intake $(\mathrm{P}>0.05)$, but there was a positive correlation with the degradation rate of NDF $(\mathrm{P}<0.05)$, respectively. The degradation rate was positively and negatively correlated with EDF and RF2 $(\mathrm{P}<0.05)$. Thus, it indicates an indirect and positive association between RAN and NDF intake.

In short, this group of parameters should be considered in production systems in the attempt of optimizing the NDF intake.

Since the sizes of potentially degradable and undegradable fraction are inherent characteristics of the substrate (Ørskov, 2000), the increase in the NDF intake can be obtained by quality and quantity management of forage mass available for grazing (Paulino et al., 2001). It would allow increasing the proportion of potentially degradable NDF fraction. On the other hand, the interaction between supplements and forage NDF should prioritize the establishment of optimal NAR levels and the maximization of rumen flow of fibrous particles and the degradation rate of potentially degradable NDF.

\section{Conclusions}

The minimal level of $7 \%$ of crude protein, on dry matter basis, is necessary for rumen microorganisms to present full capacity for using low-quality forage. This crude protein level corresponds to a minimal concentration of $6.24 \mathrm{mg}$ of ammonia nitrogen/dL of rumen fluid.

\section{Literature Cited}

ALLEN, M.S. Physical constrains on voluntary intake of forages by ruminants. Journal of Animal Science, v.74, p.3063-3075, 1996.

ARROQUY, J.I.; COCHRAN R.C.; NAGARAJA, T.G. et al. Effect of types of non-fiber carbohydrates on in vitro forage fiber digestion of low-quality grass hay. Animal Feed Science and Technology, v.120, p.93-106, 2005.

CASALI, A.O.; DETMANN, E.; VALADARES FILHO, S.C. Influência do tempo de incubação e do tamanho de partículas sobre os teores de compostos indigestíveis em alimentos e fezes bovinas obtidos por procedimentos in situ. Revista Brasileira de Zootecnia, v.37, p.335-342, 2008.

COELHO DA SILVA, J.F.; LEÃO, M.I. Fundamentos de nutrição dos ruminantes. Piracicaba: Livroceres, 1979. 380p.

COSTA, V.A.C.; DETMANN, E.; VALDARES FILHO, S.C. et al. Degradação in vitro da fibra em detergente neutro de forragem tropical de baixa qualidade em função de suplementação com proteína e/ou carboidratos. Revista Brasileira de Zootecnia, v.37, p.494-503, 2008.

DelCURTO, T.; COCHRAN, R.C.; HARMON, D.L. et al. Supplementation of dormant Tallgrass-Prarie forage: I. Influence of varying supplemental protein and (or) energy levels on forage utilization characteristics of beef steers in confinement Journal of Animal Science, v.68, p.515-531, 1990.

DETMANN, E.; QUEIROZ, A.C.; CECON, P.R. et al. Consumo de fibra em detergente neutro por bovinos em confinamento. Revista Brasileira de Zootecnia, v.32, p.1763-1777, 2003.

DETMANN, E.; PAULINO, M.F.; CABRAL, L.S. et al. Simulação e validação de parâmetros da cinética digestiva em novilhos mestiços suplementados a pasto por intermédio de sistema in vitro de produção de gases. Revista Brasileira de Zootecnia, v.34, p. 2112-2122, 2005.

DETMANN, E.; PAULINO, M.F.; VALADARES FILHO, S.C. Avaliação de alimentos ou de dietas? Uma abordagem conceitual. In: SIMPÓSIO DE PRODUÇÃO DE GADO DE CORTE, 6., 2008, Viçosa, MG. Anais... Viçosa, MG: SIMCORTE, 2008. p.21-52.

ELLIS, W.C.; MATIS, J.H.; HILL, T.M. et al. Methodology for estimating digestion and passage kinetics of forages. In: FAHEY JR., G.C. (Ed.) Forage quality, evaluation, and utilization. Wisconsin: American Society of Agronomy, 1994. p.682-756.

EL-SHAZLY, K; DEHORITY, B.A.; JOHSON, R.R. Effect of starch on the digestion of cellulose in vitro and in vivo by rumen microorganisms. Journal of Animal Science, v.20, p.268273, 1961.

HANNAH, S.M.; COCHRAN, R.C.; VANZANT, E.S. et al. Influence of protein supplementation on site and extent of digestion, forage intake, and nutrient flow characteristics in steers consuming dormant Bluestem-Range forage. Journal of Animal Science, v.69, p.2624-2633, 1991.

HOOVER, W.H. Chemical factors involved in ruminal fiber digestion. Journal of Dairy Science, v.69, p.2755-2766, 1986.

KÖSTER, H.H.; COCHRAN, R.C.; TITGEMEYER, E.S. et al. Effect of increasing degradable intake protein on intake and digestion of low-quality Tallgrass-Prarie forage by beef cows. Journal of Animal Science, v.74, p.2473-2481, 1996.

LAZZARINI, I. Consumo, digestibilidade e dinâmicas de trânsito e degradação da fibra em detergente neutro em bovinos alimentados com forragem tropical de baixa qualidade e compostos nitrogenados. 2007. 53f. Dissertação (Mestrado em Zootecnia) - Universidade Federal de Viçosa, Viçosa, MG, 2007.

LENG, R.A. Supplementation of tropical and subtropical pastures for ruminant production. In: GILCHRIST, F.M.C.; MACKIE, R.I. (Eds.) Herbivore nutrition in the subtropics and tropics. Craighall: The Science Press, 1984. p.129-144.

MERTENS, D.R. Gravimetric determination of amylase-treated neutral detergent fiber in feeds with refluxing in beakers or crucibles: collaborative study. Journal of AOAC International, v.85, p.1217-1240, 2002.

MERTENS, D.R. Rate and extent of digestion. In: DIJKSTRA, J.; FORBES, J.M.; FRANCE, J. (Eds.) Quantitative aspects of ruminant digestion and metabolism. 2.ed. Wallingford: CABI Publishing, 2005. p.13-47.

MINSON, D.J. Forage in ruminant nutrition. San Diego: Academic Press, 1990. 483p.

MYERS, R.H. Classical and modern regression with applications. Boston: PWS-Kent Publishing Co, 1990. 488p.

MOULD, F.L.; ØRSKOV, E.R.; MANNS, O. Associative effects of mixed feeds. I. Effects of type and level of supplementation and the influence of the rumen fluid $\mathrm{pH}$ on cellulolysis in vivo and dry matter digestion of various roughages. Animal Feed Science and Technology, v.10, p.15-25, 1983.

NATIONAL RESEARCH COUNCIL - NRC. Nutrient requirements of dairy cattle. 7.ed. Washington: Academic Press, 2001.381p.

PAULINO, M.F.; DETMANN, E.; ZERVOUDAKIS, J.T. et al. Suplementos múltiplos para recria e engorda de bovinos em pastagens. In: SIMPÓSIO DE PRODUÇÃO DE GADO DE CORTE, 2., 2001, Viçosa, MG. Anais... Viçosa, MG: SIMCORTE, 2001. p.187-233. 
PAULINO, M.F.; ZERVOUDAKIS, J.T.; MORAES, E.H.B.K. et al. Bovinocultura de ciclo curto em pastagens. In: SIMPÓSIO DE PRODUÇÃO DE GADO DE CORTE, 3., 2002, Viçosa, MG. Anais... Viçosa, MG: SIMCORTE, 2002. p.153-196.

PAULINO, M.F.; DETMANN, E.; VALADARES FILHO. S.C. Suplementação animal em pasto: energética ou protéica? In: SIMPÓSIO SOBRE MANEJO ESTRATÉGICO DA PASTAGEM, 3., 2006, Viçosa, MG. Anais... Viçosa, MG: SIMFOR, 2006. p.359-392.

ØRSKOV, E.R. The in situ technique for the estimation of forage degradability in ruminants. In: GIVENS, D.I.; OWEN, E.; AXFORD, R.F.E. et al. (Eds.) Forage evaluation in ruminant nutrition. London: CAB International, 2000. p. $175-188$.

ØRSKOV, E.R.; McDONALD, I. The estimation of protein degradability in the rumen from incubation measurements of feed weighted according to rate passage. Journal of Agricultural Science, v.92, p.499-503, 1979.

ORTIZ-RUBIO, M.A.; ØRSKOV, E.R.; MILNE, J. et al. Effect of different sources of nitrogen on in situ degradability and feed intake of Zebu cattle fed sugarcane tops (Saccharum officinarum). Animal Feed Science and Technology, v.139, p.143-158, 2007.

SAMPAIO, C.B.; DETMANN, E.; PAULINO. M.F. et al. Intake and digestibility in cattle fed low-quality tropical forage and supplemented with nitrogenous compounds. Scientia Agricola, 2009 (in press).
SATTER, L.D.; SLYTER, L.L. Effect of ammonia concentration on rumen microbial protein production in vitro. British Journal of Nutrition, v.32, p.199-208, 1974.

SILVA, D.J.; QUEIROZ, A.C. Análise de alimentos: métodos químicos e biológicos. 3.ed. Viçosa, MG: Editora UFV, 2002. 235p.

SOUZA, G.S. Introdução aos modelos de regressão linear e não-linear. Brasília: EMBRAPA-SPI, 1998. 505p.

UDÉN, P.; COLUCCI, P.E.; Van SOEST, P.J. Investigation of chromium, cerium and cobalt as markers in digesta. Rate of passage studies. Journal of Science Food and Agricultural, v. 31, p.625-632, 1980.

Van MILGEN, J.; MURPHY, L.L.; BERGER, L.L. et al. A compartmental model to analyze ruminal digestion. Journal of Dairy Science, v.74, p.2515-2529, 1991.

Van SOEST, P.J. Nutritional ecology of the ruminant. 2.ed. Ithaca: Cornell University Press, 1994. 476p.

VIEIRA, R.A.M.; PEREIRA, J.C.; MALAFAIA, A.M. et al. The influence of elephant grass (Pennisetum purpurem Schum. Mineiro variety) growth on the nutrient kinetics in the rumem. Animal Feed Science and Technology, v.66, p.197-210, 1997.

WILLIANS, C.H.; DAVID, D.J.; IISMA, O. The determination of chromic oxide in faeces samples by atomic absorption spectrophotometry. Journal of Agricultural Science, v.59, p.381-385, 1962.

WALDO, D.R.; SMITH, L. W.; COX, E. L. Model of cellulose disappearance from the rumen. Journal of Dairy Science, v.55, p.125-129, 1972. 